\title{
Erratum to: Vedolizumab: A Review of Its Use in Adult Patients with Moderately to Severely Active Ulcerative Colitis or Crohn's Disease
}

K. P. Garnock-Jones

Published online: 15 January 2015

(C) Springer International Publishing Switzerland 2015

Erratum to: BioDrugs (2014)

DOI 10.1007/s40259-014-0113-2

The author has alerted us to the following error:

Table 2, Section 4.2: The cell entry in the 'Population' column which previously read:

"TNF-agonist-naïve"

should read:

"TNF-antagonist-naïve"

The online version of the original article can be found under doi:10.1007/s40259-014-0113-2.

K. P. Garnock-Jones ( $\square)$

Springer, Private Bag 65901, Mairangi Bay,

0754 Auckland, New Zealand

e-mail: demail@springer.com 